Meta

Journal des traducteurs

Translators' Journal

\title{
Dubbing Multilingual Films: A New Challenge?
}

\section{Christine Heiss}

Volume 49, numéro 1, avril 2004

Traduction audiovisuelle

Audiovisual Translation

URI : https://id.erudit.org/iderudit/009035ar

DOI : https://doi.org/10.7202/009035ar

Aller au sommaire du numéro

Éditeur(s)

Les Presses de l'Université de Montréal

ISSN

0026-0452 (imprimé)

1492-1421 (numérique)

Découvrir la revue

Citer cet article

Heiss, C. (2004). Dubbing Multilingual Films: A New Challenge? Meta, 49(1), 208-220. https://doi.org/10.7202/009035ar

\section{Résumé de l'article}

Au cours de la décennie écoulée, le nombre de films produits dans les pays germanophones, avec en situation de communication plurilingue a augmenté de façon considérable. Dans ces films, la composante interlinguistique devra être prise en compte en plus de la nécessité de restituer les informations (sur les personnages et l'histoire) transmises moyennant les variations intralinguistiques qui ne devraient jamais être estompées dans la version doublée. À une telle multiplicité de langues et à la présence de plusieurs variations linguistiques pourraient correspondre divers types de traduction filmique. Des innovations technologiques telles que le DVD pourraient offrir des produits de traduction filmique plus indiqués pour faire face aux nouveaux défis des films plurilingues et prendre en compte la sensibilité linguistique de groupes de spectateurs différents de la culture cible. 


\title{
Dubbing Multilingual Films: A New Challenge?
}

\author{
CHRISTINE HEISS \\ University of Bologna, Forli, Italy \\ heiss@sslmit.unibo.it
}

\section{RÉSUMÉ}

Au cours de la décennie écoulée, le nombre de films produits dans les pays germanophones, avec en situation de communication plurilingue a augmenté de façon considérable. Dans ces films, la composante interlinguistique devra être prise en compte en plus de la nécessité de restituer les informations (sur les personnages et l'histoire) transmises moyennant les variations intralinguistiques qui ne devraient jamais être estompées dans la version doublée. À une telle multiplicité de langues et à la présence de plusieurs variations linguistiques pourraient correspondre divers types de traduction filmique. Des innovations technologiques telles que le DVD pourraient offrir des produits de traduction filmique plus indiqués pour faire face aux nouveaux défis des films plurilingues et prendre en compte la sensibilité linguistique de groupes de spectateurs différents de la culture cible.

\begin{abstract}
Over the last ten years the number of films produced in the German speaking countries in which the communication takes place in more than one language has increased substantially. In addition to the necessity to render the information on the characters and plot transmitted by 'intralinguistic' variations which should never be flattened out in the dubbed version, interlinguistic differentiation must be taken into account in these films as well. A multiplicity of languages and different linguistic variations might therefore require a multiplicity of modes in film translation. Technical innovations like DVD might now open new possibilities to offer products of film translation which are better suited to deal with the new challenges presented by plurilinguistic films and to meet the linguistic sensibilities of different audience groups in the target culture.
\end{abstract}

\section{MOTS-CLÉS/KEYWORDS}

dubbing, DVD, linguistic variations, multilingualism, target audiences

One of the most famous films in which the action is based on the use of different national languages is Le Mépris (1963, Jean-Luc Godard). One can see what problems the film translation industry had with this by the levelled out dubbing adopted in different countries (Italy, Germany, etc. $)^{1}$ each of which raised the particular target language to the status of the main language of communication in the film, thereby not only creating an unnatural communication situation, but also rendering one professional figure utterly superfluous, namely the interpreter. When one considers that in the dubbed version the film audience was presented with a person, who spent part of her time repeating words in a meaningless fashion and partly reciting senseless, newly invented chunks of dialogue, one comes to the inevitable conclusion that the dubbing studios entrusted with cultural mediation were quite oblivious to the problems attached to multilingualism in films. It is undoubtedly true that at the time it was being shown in cinemas, Le Mépris, with its dialogues in different national 
languages, constituted a special case. Yet traces of the phenomenon of multilingualism, or at least code mixing and code switching, have always been present, not only in European but also in Hollywood films. One need only think of the way ethnic minorities are introduced by interjections in their mother tongue; these are then followed through in the English dialogue, with the help of accents. Or else there is the German villain's way of speaking (e.g. Peter Lorre). These are the linguistic peculiarities considered typical of certain characters, but which in the dubbed versions have often been eliminated. In these films, unlike Le Mépris and other multilingual films, English was the dominant language of communication even though they were set and produced in a de facto multicultural society.

\section{Multilingualism in film productions in the German-speaking countries}

The linguistic situation in a Europe which in the last three decades of the 20th century became more culturally diverse and, at the same time, was drawn closer together economically and politically presents a particularly complex picture, due to the many different national languages that live side by side and enjoy equal rights. The migration of refugees and people in search of work to countries such as Austria and Germany has led to arguments about the appropriateness of employing interpreter services in the social sector, as a large proportion of these immigrants do not have a good command of the national language. ${ }^{2}$ Political debates between the CDU/CSU coalition and the SPD over the Green Card and the regulation of migration or immigration to Germany, the words of Jörg Haider against foreigners in Austria, and the success of populist politicians in Switzerland should all be seen as a reaction to the existence of a de facto multicultural society in German-speaking lands.

Films are a reflection of reality; indeed, sometimes they even anticipate reality. It is no wonder then that cultural difference and the consequent linguistic difference, at least since the guest worker question first arose, has occupied a firm place in German language films. One need only think of films by Rainer Werner Fassbinder (Katzelmacher, 1969, Angst essen Seele auf, 1973), but also earlier films (Krambambuli, 1940, Karl Köstlin), which could still be classified as belonging to the genre of 'films about the homeland' (Heimatfilm).

However, it was primarily in the ' 80 s and ' 90 s that the number of film productions requiring the audience to deal with communication in more than one language increased. For one thing, film producers wanted German language films to be fit for global competition and more and more frequently gave signs of this by using English language titles. Representative of this trend were Funny Games (1997, Michael Haneke), Knockin' on Heaven's Door (1997, Thomas Jahn) and Crazy (2000, HansChristian Schmidt) etc. Sometimes even English dialogue is woven into the script, and the languages of bordering countries, of different language minorities or immigrant groups, are introduced in single interjections (hence, for example, the use of Dutch or Turkish in Knocking on Heaven's Door).

Of course, in such cases the multicultural society is to the fore: in Happy Birthday, Türke (1992, Doris Dörrie) the first and second generation 'Turkish German' speakers only appear as film characters or rather as characters from a novel. Since that time Germans of Turkish origin have become directors of multilingual films 
themselves (Lola and Billidikid 1999, Kutlug Atamann; Sommer in Mezra 1991 and Ich Chef, du Turnschuh 1999, Hussi Kutlucan, to give but a few examples). Other language combinations appear too, like German and Russian in Luna Papa (1999, Nerab Nimizde, Bakhtiar Khudojnazarov). ${ }^{3}$ Finally, in Code Inconnu (2000, Michael Haneke) the Internet Movie Data Base (IMDB) mentions as many as six languages (French, German, Romanian, Malinka, English and Arabic), to which sign language is also added.

The linguistic 'amalgam' (in which several national languages exist alongside each other in their standard form) is rendered all the more complicated by the conscious emphasis placed on regional variants or the specification of social strata, in a certain way to be seen as opposed to globalisation. Social and regional variations as well as dialects exist in many of these films, next to the 'standard' language, which in turn is often interspersed with 'coinings,' loan constructions or calques taken from American English: this is a recurrent feature of televised films dubbed into German. ${ }^{4}$

\section{Nordrand as an example}

Nordrand (1999, Barbara Albert), an Austrian film which received an award at the Venice Film Festival, is an example of this kind of film. The multiethnic society determines the action. At the time of the Balkan War people of different nationalities meet at Nordrand ${ }^{5}$, on the outskirts of Vienna. Young people of Serbian, Italian and Croatian extraction, some of them second generation, lead a more or less marginal existence. However, significantly, it is the members of an underprivileged Austrian family who are the real marginalised people in the film. The anti-hero of the film is one of the daughters, Jasmin, whose rebellion has self-destructive features to it.

Thus, at a linguistic level the film presents a very complex picture: the main language of communication in the film is Austrian German ${ }^{6}$, yet this immediately breaks down into a number of different facets which are of great significance for the portrayal of the individual characters:

- Colloquial speech which in pronunciation and word choice presents Viennese-Austrian features, and is grammatically fairly correct; interestingly, this is spoken by Tamara, a second generation Serb (bist' deppert; wart'; Spital; the typical Austrian openers Geh' bitte or Geh'; Baba when taking one's leave, etc.).

- Colloquial Viennese which is spoken for example by Tamara's 'superior' at the hospital, Gitti, and is introduced aptly when Tamara is being humiliated. (Was stehst' $n$ so deppert umadum).

- A relatively authentic Viennese accent of the underprivileged ${ }^{7}$ (spoken some of the time by Jasmin, her family and some of her friends as well as by secondary characters) and which apart from the pronunciation is especially evident in the choice of words (leiwandene Hawarer; Halt' die Pappm).

The dialogues are extremely true to life and typical of the milieu that is represented. One thing that is striking about them is the frequent use of the Austrian modal particle $e h^{8}$, which is to be found mostly in the dialogues between Tamara and Jasmin, but also among native Austrian speakers' dialogues. Other modal particles that often crop up are $j a$, doch and halt. ${ }^{9}$ We can also find:

- Various expressions from foreigners' German, or rather foreigners' Austrian, with typical cliché-ridden mistakes in pronunciation or grammar, especially through the use of 
the infinitive or the omission of articles (e.g. the figure of the refugee smuggler; Valentin, a character probably of Czech extraction; the character from a Russian background): Ich lassen euch jetzt alleine; Ihr weitergehen; Ich habe gefunden ...in Donau.

- The German of TV broadcasts with speakers from the Federal Republic.

- The Austrian radio announcer speaking standard (Austrian) German.

This is merely a first attempt to divide up the multitude of phenomena within a linguistic system which undoubtedly lends itself to further differentiation. On top of this, now on an interlinguistic level, come the various foreign languages:

- English as the language of communication of various nationalities, sometimes spoken incorrectly.

- Foreign TV programmes with subtitles, in Serbo-Croat, etc.

- Greetings and toasts from other languages; scraps of Italian.

- Dialogues in Serbo-Croat (with German subtitles)

- Russian and Czech dialogues (with German subtitles)

\section{Is it at all possible to dub multilingual films?}

What exactly does all this mean for the reception of such a film by audiences abroad? Are there feasible ways of translating films creatively?

In the world of film dubbing it may well be considered a truism that one cannot translate one dialect into another, because if this is attempted cultural anchoring will suffer and the image will be belied. ${ }^{10}$ Of course there are exceptions to this rule. Certain genres, such as comedies, for example, are in a certain sense perceived as being detached from reality and therefore offer more room for 'unorthodox' solutions in film translation. The sporadic use of small dialectal insertions, on the other hand, will not alter or influence the overall impression for the worse in other genres.

Now, are the characters in films like Nordrand all condemned to speak in the same way in the dubbed version? And in which standard language (or rather 'dubbese') should they speak? The studies undertaken thus far of dubbing into German and Italian ${ }^{11}$ show that in both languages a series of suitable means are available to characterise the various ways of speaking of the individual characters in a manner that makes them distinguishable from one another; this is also applicable to other languages. Compensation can be made at a syntactic level (with pauses, interrupted sentences, anacoluthons, left and right shifting, etc.); at a lexical level (with the particular choice of words, neologisms, as well as class and age-specific vocabulary); and at a pragmatic level (with discourse markers, modal particles, false starts or other features of oral language). At a phonetic level it is possible to reproduce typical accents (for example, a German accent or various ethnic accents). ${ }^{12}$ Unfortunately it is inevitable that in all cases something of the atmosphere is lost. ${ }^{13}$ That said, the creative use of these means could produce dubbed versions that are much more satisfying and appropriate than those containing the smoothed over and levelled out 'dubbese' so often presented in the so-called dubbing countries.

It is particularly important not to unify the language in cases of bilingualism (cf. 3.3.1. $)^{14}$ and code switching with functional load, in the dubbed version, because otherwise important information about characters and social imbedding would be lost on the audience. Of course, the translator who does the first draft has an important function at this point. S/he has to be able - as for example in the case of Nordrand - to 
recognize the various nuances and to impart the appropriate suggestions and information to adapters and dialogue writers, since teamwork is a common practice in the dubbing industry.

\subsection{Some examples of differentiated transposition at the level of 'inter-language'}

In the dubbed versions of the films cited below compensations are made concerning varieties, social and regional variations as well as dialects, idiosyncratic manners of speaking, etc.: ${ }^{15}$

- The German of foreigners - clearly faulty language at different levels (lexis, syntax, and phonetics) is often introduced in the form of clichés. This can be reproduced without any difficulty, as long as the translator of the first draft recognizes them as such. The following example is taken from the film Knockin' on Heaven's Door ${ }^{16}$, and the speaker is Abdul, a Turkish character played by Moritz Bleibtreu. Similar examples were to be found in numerous other films ${ }^{17}$ too. The typical mistakes with articles, gender and prefixes in the original version are rendered with the help of errors of syntax and incorrect morphology:

Abdul:

Frankie! Die waren diese Bullenschweine! Die haben die Geld geklaut! Die sind alle beruppt! (...) Korrupt!

Abdul:

Frankie! È stati porci sbirri! Loro fregato soldi! Quelli essere tutti rotti! (...) corrotti!

- Fiore's idiosyncratic way of talking, interspersed with discourse markers, in Mimì Metallurgico (1972, Lina Wertmueller) was characterised in German by the frequent use of modal particles: ${ }^{18}$

Fiore: Ooh, uù te...ma sei matto! Figuriamoci se lo faccio per favore...uè, ma non sono mica robe, che si fanno per favore, queste qua ... io sono anche vergine.

Fiore: (...) Oh, so hat er sich das vorgestellt! Das sind ja schöne Sitten. Du spinnst wohl 'n bißchen,wie? So 'was tut man doch nicht aus purer Gefälligkeit! Außerdem bin ich Jungfrau!

- In the same film, Mimìs Sicilian way of speaking and word order is rendered at the syntactic level by Ausklammerung ${ }^{19}$ in the German version.

Mimì: (...) Tu femmina sei e non ti devi occupare dell'eleganza maschile. Tu sei nata per fare la maglia e pe'fare queste arlecchinate che mi costringi a portare.(...) E inoltre sei nata per fare l'amori!

Mimi: (...) Du bist nur eine Frau und hast dich nicht zu kümmern um die männliche Eleganz. Du bist geboren zum Nähen und zum Stricken, damit du mich in solche Narrenkostüme zwängen kannst. (...) Und ansonsten bist du geboren für Amore.

Other examples will have to be left out for want of space. However, it would be possible, with a certain amount of patience, to put together all the characteristics listed in section 3 of both the Italian/German and the German/Italian dubbing (and the same could be done for other language combinations). ${ }^{20}$ 


\subsection{Examples of the flattening out of 'interlanguage' differentiation}

The fact that differentiated intralinguistic nuances have not always been a matter of course is demonstrated by the example of the translation of the title of Rainer Werner Fassbinder's Angst essen Seele auf. In the Italian title, La paura mangia l'anima, the typical cliché-ridden foreigners' German, which was introduced quite intentionally in the original title, was made grammatically correct, even though it would have been possible to produce an equally effective infinitive construction in Italian: Paura mangiare anima. The title of the English version is corrected in a similar way: Ali: Fear Eats the Soul. Naturally, to a certain extent titles constitute their own text type, ${ }^{21}$ and film titles in particular are subject to changes of the most varied kinds, for they are there to entice the public into the cinema. Therefore, in many cases the title of the foreign language film version expresses the idea that the particular distribution company has of the expectations of the target audience. The aim or scopos of the translated title is primarily a commercial one. Often information about the complexity of the social realities, which, as in Fassbinder's case, can be reflected in the very title by linguistic means, is inadequate. And with Fassbinder's films it was not even a question of luring masses of visitors to the cinema to watch mainstream films. Even today it is commonly assumed that to confront the target audience with different languages is asking too much, and that there is little inclination to accept multi-layered linguistic and social realities. ${ }^{22}$

Examples of flattening out and the formalisation of authentic-sounding spoken language are to be found in almost all dubbed versions, whatever the genre. The care with which the translation is carried out depends in many cases on the financial means available. It is particularly common for cheap television productions to have an especially high degree of formal, wooden language. ${ }^{23}$ Yet in many other cases there still seems to be a lack of awareness during the dubbing process of how important differentiation can be at an intra-language level for the development of the plot and consequently also for the effect it has on the audience. Examples like the ones cited below were to be found in almost all the films referred to in this article, and in others besides. This has absolutely nothing to do with evaluating the films as having been 'well' or 'badly' dubbed, but rather with the problematical nature of the widespread practice of trying to meet the presumed expectations of the target audience.

- In an important scene at the beginning of Nordrand, Tamara's 'superior,' Gitti, switches from Viennese city dialect to standard language, whereby the use of the Viennese dialect is intended to humiliate Tamara. In the Italian version the only compensation is made at an idiomatic level:

Gitti: Tamara, was stehst'n so deppert umadum ...? Nein, das Kind braucht sie jetzt nicht, bist du schon ganz... Mitdenken, Schatzi, immer mitdenken, sonst wird das nichts mit uns zwei. (...)

Gitti: Tamara, non darle il bambino adesso, dove hai la testa? Ragiona, signorina, mettici un po' di cervello! Se no qui non andiamo d'accordo!

- In the difficult task of translating lower-class expressions, the comprehension of the Italian translator/adaptor of Nordrand is rescued through the screen image. While the family is watching TV a bride dressed in white is shown on horseback with her Prince Charming. Jasmin, the anti-hero in the film, has just discovered that she is pregnant 
and there is no prospect of the father coming forward. In these circumstances, her mother's remark (that sooner or later Jasmin will get herself pregnant) must seem all the more cutting. Since the (almost untranslatable) dialect expression leiwandene Hawarer is substituted by the standard principe azzurro ${ }^{24}$ in the Italian version, the only hint that lower-class language is being used is the retention of the unclear pronunciation.

Mutter: Na wart es ab, bis einer von deinen leiwandenen Hawarern dir ein Kind andraht, dann schaust anders aus.

Madre: Grazie! Sta' lì a aspettare il principe azzurro e, al primo che ti mette incinta ne riparliamo!

- In the dialogue sequence between Valentin and a character who clearly comes from a Russian background, both Valentin and his interlocutor speak with a strong accent and make syntactic errors. (In a further dialogue sequence, both of them switch to Russian.) At the end of the dialogue Valentin's interlocutor introduces a few Italian words. This switch is taken up by Valentin, albeit in a somewhat parodical and slightly aggressive fashion. In the Italian version both characters are dubbed without any accent, even though here too it is really necessary to signal the problems with the main language of communication and the readiness to switch codes in order to bring out the characterisation of these two people. There are also other cases where the characterisation of the broken German of foreigners, or rather the Austrian of foreigners, in its multiple gradations and degrees of accuracy, is made to sound too perfect in the dubbed versions. As a result, the forcefulness of expression is removed both from the characters and from the representation of the social milieu.

These are just a few examples, which could easily be added to from this and other films.

\subsection{Modes of translation of multilingual films}

The unfortunate argument over whether subtitles are to be preferred to film dubbing is clearly out of place in the case of multilingual films, because in such films both forms need to be adopted. A current example of this is the use of subtitles for the foreign language embedded in the "language of communication" (e.g. foreign television, the insertion of speech in a foreign language and dialogues in one or several foreign languages); that is to say, in situations in which the foreignness should be retained in the target language as well, while at the same time the dialogues in the "main language of communication" are translated through the process of dubbing. With the accumulation of languages and communication situations (e.g. background information relevant to the plot by blending in foreign language television programmes plus simultaneous dialogue in another foreign language $)^{25}$ it might be sensible to test to see whether the use of voice over (a form of film translation which is used in western countries mostly for film documentaries) could help with differentiation.

This too is a first rough division at the level of modes of film translation (dubbing, subtitles, voice over) which naturally concerns the question of multilingualism in the sense of several languages existing alongside each other rather than the constantly thorny question of the rendering of accent, dialect and regional varieties in screen translation and especially in film dubbing. ${ }^{26}$ 


\subsection{The reduction of translation modes}

As we have already pointed out above in our discussion of the translation of Fassbinder's Angst essen Seele auf, besides translation problems resulting from financial limitations, linguistic flattenings out are undertaken, sometimes due to a misguided consideration of the target audience. This is for fear that the average watcher will be confused, and perhaps there is also a fear of frightening filmgoers away, thus reducing the success and earnings. One example of this concern is the discussion that still goes on in some Italian dubbing studios as to how foreign proper names should be pronounced; whether in the Italian way, in order not to clash with what the public is used to, or in the correct original form, which could naturally serve to educate the public with regard to foreign languages.

Justified as being "a concession" made to the audience (whereby of course the financial means available could play a significant role) translation modes are also trimmed. Some examples will be discussed below.

\subsubsection{Leaving out subtitles when these are present in the original. Here are some examples from Nordrand:}

- Tamara speaks to her mother in Serbian on the telephone. The conversation begins in Serbian and is reproduced in the original version with German subtitles. When Tamara's brother comes to the phone there is a code switch to Austrian German, which is an important signal for the linguistic characterisation of the second generation. In the Italian version the whole conversation is dubbed into Italian. Valuable information is lost about the multiethnic nature of Vienna following the Balkan War as well as about the linguistic and cultural behaviour of the second generation of an immigrant group; these people often speak both languages fluently and switch from one to the other, according to the situation.

- Tamara meets a Serbian friend in a discotheque, which is clearly a meeting point for this immigrant group in Vienna. The greeting and the preliminary conversation take place in Serbian with German subtitles provided. Tamara then effortlessly switches to German (Ist der Milan da) and once again receives a reply from her friend in Serbian. This linguistic behaviour is typical of the second generation. A reduction to a single language conversation between friends in a disco, as is favoured in the Italian version, does not do justice to the representation of a multiethnic environment in Vienna; the filmgoer is therefore deprived of important information.

\subsubsection{Subtitles in one language for a multilingual film}

The decision to choose only subtitles for a multilingual film as a translation model can be just as problematical. ${ }^{27}$ This is true, for example, of the film Lola and Bilidikid (1999, Kutlug Ataman), the original version of which is German/Turkish, the Turkish dialogue sequences having German subtitles. In the Italian subtitled version both the Turkish and the German parts have Italian subtitles. In all probability the average Italian filmgoer realises that there are two languages and two cultures in the original version - after all, German and Turkish are two very different languages. In addition to this there is the fact that although the film was shown in the cinemas/ on general release, the videocassette by e.mik was aimed primarily at a public that was above average in education and interest. However, one should not underestimate the risk that people will simply overlook cultural differences when being presented with nothing but single-language subtitles. A version which had subtitles and dubbing 
built into it would place greater demands on the audience but would correspond more closely to the cultural diversity presented in the film. ${ }^{28}$

All in all, in the long or short term the social development in Italy, among other countries, will lead to interlanguage multilingualism, a social reality which certainly will be reflected in films too. At the level of dialect, multilingualism has been granted access to Italian film productions for a long time now. The presence of new minorities (Albanians and Chinese) will also make itself felt soon in the linguistic reality and thus sooner or later in Italian film productions, because social contrasts create tension and are therefore highly suitable to be portrayed on the big screen.

Aside from the need for increased language competence among those who participate in the dubbing process, it might also be necessary to insert the different modes of film translation side by side to a greater extent than has been the case hitherto. Thus, perhaps it will be possible to change and differentiate the viewing habits of filmgoers in the countries where dubbing is prevalent.

\section{New technical possibilities for film translation through different versions on DVD}

For many years now a large percentage of cinema films have sooner or later found their way onto the market as home videos for sale or loan, either in a dubbed or a subtitled version. With the introduction of DVDs new possibilities have arisen for the "use" of dubbed films. For the most part, in addition to a series of other options regarding choice of scene, of commentary, of director's comments, etc., the following versions are on offer: an original version with subtitles in the target language of the particular country where it is sold (sometimes also with subtitles in the source language), and a dubbed version (with subtitles for the deaf on demand). With some films one can even find two versions which are dubbed in different target languages (Italian and Spanish, for example). Altogether there is room for "...8 different soundtracks (the original plus max. seven dubbed versions) plus 32 different sets of subtitles for the same film (interlingual subtitles in a number of different languages as well as intralingual subtitles for different audiences: the deaf and hard of hearing, young viewers, etc. (Gambier:\& Gottlieb 2001, xiii). The production of DVDs is still restricted to films whose success is predictable, i.e. mostly to big, mainstream productions. The films produced in Germany cited above can hardly be expected to appear on DVD. However, in theory this technique provides the interested "user" with the chance - according to his competence in the language - to watch the film in the original version, often with the help of subtitles in the source language which translate the dialogue almost in its entirety, and to compare it with the dubbed version. In many cases the very first discovery that the critical, language-competent film consumer will make will be that the accents have been flattened out. (One of the more recent examples that can be mentioned here is the loss of the Scandinavian accents in the Italian version of Catherine Bigelow's The Weight of the Water.) It is to be hoped that the possibility of making such comparisons will also increase the pressure on the dubbing industry to deliver products of a high quality from a linguistic point of view. 


\subsection{The target audience and targeted film translation in the age of the DVD}

In the context of the hitherto still very rare attempts to establish a theoretical basis for film translation, it is pointed out again and again how very hard it is to determine with any accuracy just who the target audience is. ${ }^{29}$ There is no doubt that the identity of the target audience plays an important part in choosing the mode in which the feature film is to be translated, especially if a choice has to be made between subtitling and dubbing. ${ }^{30}$ Indeed, the broad target audience in the cinemas in so-called dubbing countries is as hard to identify as ever. In larger towns those interested in foreign language films are still offered arts cinemas showing the original or subtitled versions, or they may even offer a simultaneous translation - provided these cinemas survive in the ever more competitive market of the future. For the home market, it would be possible (as long as it is economically viable) to produce versions that are aimed at a more restricted audience (e.g.multilingual $+x y z$ ), where the unknown factors could be established from one case to another (e.g. language minorities; a linguistically accomplished audience; interest in the genre; interest in the plot, etc.). As was pointed out at the beginning, the language quality of the film version in the foreign language is closely related to the conceptions held by the distributors of the target audience.

Films on DVD, providing the opportunity to switch from one language to another, would be especially useful in countries where a part of the population is bilingual or where a part is made up of language minorities. (Think of Belgium, for example, or the autonomous province of South Tyrol in Italy, or else, to leave Europe for once, the ever growing Spanish-speaking minority in the USA.)

Films on DVD could also contribute to the acquisition by a minority of the dominant language of the country. Here too the possibility of 'mixed' translation modes could prove a success. In recent years there has been increasing discussion among researchers about the use of subtitles in language acquisition and the use of subtitles in foreign language teaching has already been successfully put into practice (Heiss 2000b; Danan, in this volume). A film like Luna Papa with subtitles in German and Russian, apart from being attractive to German speaking viewers, would find an ideal target audience in the group of Russian Germans who do not always have command of the German language, and also of course among the German minorities in areas of the ex-Soviet Union.

To come back to the process of screen translation, film versions on DVD (with commentaries, explanations and the possibility for the user to switch to the original film versions, perhaps with the help of subtitles in the source language) can give the film translator a better chance of taking into account the function of the film in the target culture. In this way the demands of our modern multi-ethnic, multi-cultural globalised society would be better served. Thus, by means of this new technique, the requirements of Vermeer's Scopos theory can be better taken into account in film translation too.

At a theoretical level, the few existing theoretical approaches in screen translation need to be adapted for multilingual films, too. Thomas Herbst (1994: 221) pleaded for a pragmatic approach in dubbing and set up a 'hierarchy of levels of equivalence' which extends from technical restrictions to the meaning of the text. He states that 
dubbed films correspond to the concept of House's covert translation (House, 1981) and should therefore as far as possible give the illusion that an original product is being 'consumed.' Viewers used to film dubbing are usually willing to accept this illusion, even though they are made thoroughly aware, both through various visual and textual messages, that a large proportion of the productions they see in the cinema and on television are of foreign origin. ${ }^{31}$ Up to now the scopos of feature films and television films has generally been considered to consist merely in entertainment. Concerning covert translation this may have led to an undue consideration of what the audience is accustomed to, as described in point 3.2 above. In the case of multilingual films (and also of films of a specific genre ${ }^{32}$ ) this ought to be extended to cover other functions. The sequence that in the original is translated overtly and which is often already accompanied by subtitles should not be concealed in the translation either. Sometimes even these are omitted and the viewer is intentionally confronted with a language s/he does not know. Considering the modern technology of the film industry, it seems rather bold to adopt Schleiermacher's concept of 'alienating translation' to explain the demand not to flatten out plurality even in the modes of translation. But it is undoubtedly true that in multilingual films a meaningful element is represented by the fact that the viewers are confronted with what is foreign to them, and this must not be lost in the translation. It can therefore be seen that the few existing endeavours to theorise the film translation are once again being faced with new challenges.

\section{NOTES}

1. Cf. Giovanni Picci (2000). Il plurilinguismo nel dialogo filmico: da Le Mépris di Jean-Luc Godard a Il Disprezzo di Carlo Ponti. Unpublished thesis, SSLiMIT Forlì.

2. Cf. Franz Poechhacker: Interpreting Needs in Europe - A Millennial Perspective. A lecture delivered at the conference "Prospettive linguistiche della nuova Europa all'alba del terzo millennio," Bocconi University, Milan - November 2001. This lecture drew attention to the problem posed by the large number of ethnic groups represented in Vienna.

3. According to the Internet Movie Data Base (IMDB), the original version of the film has German and Russian subtitles and thus would ideally be aimed at both language groups.

4. As specific examples of the genre of television thrillers being translated literally from American English, mention could be made of expressions like: "Ich schätze - I guess." For a comprehensive study of German 'dubbese' in television series, see Herbst, 1994.

5. I am grateful to Mary Pellegatta the dubbing author, who kindly put the lists of dialogues of the German and Italian versions at my disposal, and to Silvano Piccardi, the dubbing director, for a stimulating discussion. At the same time it should be mentioned that the work of the dubbing team was made that much more difficult by the absence of the international sound track and by the fact that other information was missing from the list of dialogue to be translated.

6. For a discussion of the variety of German spoken in Austria, see Muhr, 2001.

7. In most cases there is a tendency to weaken dialect in films, because although so much of the characterisation of the characters depends on it, there is still a desire to guarantee the wider audience a minimum of understanding. Cf. Rossi, 1999, 79ff.

8. On the use and function of typical Austrian particles, see Heinrich, 2001.

9. On the use and function of modal particles in film dialogues, see Heiss, 2001.

10. On the problem of accent and dialect in film dubbing, see Herbst, 1994 and 1996.

11. See Heiss, 1996, 2000a, 2001 and Heiss \& Leporati, 2000.

12. See Heiss, 1996, 2000a, 2001 and Heiss \& Leporati, 2000.

13. See Herbst, 1994.

14. Whether or not one can speak of diglossia in connection with Tamara and the 'Community' in Nordrand remains for the time being an open question. 
15. The examples were selected at random, as a comprehensive presentation of all the phenomena in paragraph 2 would go beyond the scope of this paper. In this connection, see Heiss, 1996; 2000a; 2001 and Heiss \&.Leporati 2000.

16. The examples from Knocking on Heaven's Door are taken from the unpublished degree thesis of Marilena Piccolo (SSLiMIT Forlì, academic year 1999/2000).

17. E.g. in the Italian version of Nordrand, Happy Birthday, Türke and in other films.

18. See Heiss, 2000a.

19. Ausklammerung means the shifting of a part of the sentence after the verb. Cf. Soffritti, 1988.

20. The reader is referred once more to the earlier studies by Heiss.

21. On the problems surrounding the translation of titles, see Nord, 1993.

22. Paradoxically, no such fear seems to exist with respect to Anglicisms in the dubbed versions, which audiences in dubbing countries are expected for the most part to be able to cope with. Here the dubbed language can sometimes become a vehicle for acculturation. (Whether this is intentional or results from rough translations which remain too close to the original text can be left open at this point.)

23. Cf. also Herbst, 1994. It must however be said that the German versions of some newer productions (e.g. Friends) could lead one to conclude that here too the concern was to arrive at natural sounding speech.

24. A more appropriate translation to a lower register - lip sync allowing - could have been 'fichissimo ganzo.'

25. In Nordrand, among other things there is one scene in which a television programme (in standard German) is blended in, overlapping with a subtitled foreign dialogue. The Italian version opts to leave the television programme with the original soundtrack (which the Italian filmgoer is unable to grasp) and supplies subtitles for the foreign dialogue. Maybe in this case it would have been possible to use voiceover for further differentiation and improved comprehension.

26. At this point it would naturally be worth discussing whether these subtleties in the subtitles could at least be mentioned, since there are certainly examples which lend weight to this view, see Kova?i?, 1996; Assis Rosa, 2001.

27. The author is naturally aware of the fact that in films that tend to reach a limited audience and are not expected to be box office hits, subtitles are often chosen as a translation mode for financial reasons. However, this is irrelevant to the theoretical considerations about their effect on the audience.

28. This mixing of film translation modes, using dubbing and subtitles, would certainly be more costly (and it is precisely when films are aimed at a limited public, as with e.mik, that the question of costs could be the determining factor in opting for a 'simplified' film translation).

29. See.Delabastita, 1990, Gambier \& Gottlieb, 2001. On the German works on film dubbing, see the corresponding chapter in Herbst (1994), Pisek (1996), Pruys (1997).

30. Conventions can play an important role in this, too, as can be seen by the different practices adopted by the so-called dubbing countries, or rather in the Scandinavian subtitle countries, where film dubbing is directed chiefly towards children who are not yet able to read. Economic factors may have led to the situation where in some East European countries voice over, which is otherwise reserved for the genre of documentary films, is used for feature films on television and in cinemas.

31. Thomas Herbst bases his research on a corpus of television series translated into German and this is not without significance when conclusions are drawn. The discussion of translation problems in Pygmalion constitutes an exception in his corpus, to which he applies other conditions.

32. For the correlation of genre and film translation, see Delabatista, 1990; Heiss, 2000a.

\section{REFERENCES}

Assis Rosa, A. (2001): "Features of Oral and Written Communication in Subtitling." (Multi)media translation: concepts, practices, and research. Yves Gambier and Henrik GotTlieb (eds), John Benjamins, Amsterdam, Philadelphia, pp. 213-222.

Delabastita, D. (1990): “Translation and the Mass Media." Translation, History \& Culture. Susan Basnett and André Lefevere (eds), London, Pinter Publishers Limited, pp. 97-109.

Gambier, Y. and H. Gottlieb (2001): "Multimedia, Multilingua: Multiple Challenges." (Multi)media translation: concepts, practices, and research. Yves Gambier and Henrik Gotтlieb (eds), John Benjamins, Amsterdam, Philadelphia, pp. viii-xx. 
Heinrich, W. (2001): “Zur Kärtner Partikel lei." "Modalità e substandard, Wilma HeinRich \& Christine Heiss (eds),. Bologna, CLUEB, pp. 317-342.

Heiss, C. (1996): "Die Commedia all'italiana auf deutsch: kultureller Transfer und sprachliche Anpassung." Traduzione multimediale per il cinema, la televisione e la scena, Christine HeIss and Rosa Maria Bosinelli Bollettieri (eds), Bologna, CLUEB, pp. 169-183.

Heiss, C. (1996): "Il testo in un contesto multimediale." Traduzione multimediale per il cinema, la televisione e la scena, Christine Heiss \& Rosa Maria Bosinelli Bollettieri (eds), Bologna, CLUEB, pp. 13-26.

Heiss, C. (2000a): "Quanto è tedesco Mimi Metallurgico. Qualità e strategie di doppiaggio in alcuni esempi di commedia all'italiana." Tradurre il cinema, Christopher TAYlor (ed.), Trieste, Dipartimento di Scienze del linguaggio dell' interpretazione e della traduzione, pp. 59-73. <www.intralinea.it>.

Heiss, C. (2000b): "La traduzione filmica come pratica didattica." La traduzione multimediale: quale testo per quale traduzione, R.M. Bosinelli Bollettrieri, Christine Heiss, Marcello Soffritti and Silvia Bernardini (eds), Bologna, CLUEB, pp. 183-196.

Heiss, C. (2001): "Written to be spoken. Zur rolle der MPn in originalsprachlichen und synchronisierten Filmdialogen" Modalità e substandard, Wilma Heinrich and Christine Heiss (eds), Bologna, CLUEB, pp. 261-286.

Heiss, C. and L. Leporati (2000): "Non è che ci mettiamo a fare i difficili, eh? - Traduttori e dialoghisti alle prese con il regioletto," La traduzione multimediale: quale testo per quale traduzione; Rosa Maria Bosinelli Bollettieri, Christine Heiss, Marcello Soffritti \& Silvia Bernardini (eds), Bologna, CLUEB, pp. 43-66.

Herbst, T. (1994): Linguistische Aspekte der Synchronisation von Fernsehserien. Tübingen, Niemeyer.

Herbst, T. (1996): "Why dubbing is impossible." Traduzione Multimediale per il cinema, la televisione e la scena, Christine Heiss and Rosa Maria Bosinelli Bollettieri (eds), Bologna, CLUEB, pp. 99-116.

House, J. (1981): A Model for Translation Quality Assessment. Tübingen, Gunter Narr Verlag.

Kovačıč, I. (1996). "Subtitling Strategies. A flexible hierarchy of priorities. Traduzione Multimediale per il cinema, la televisione e la scena, Christine Heiss \& Rosa Maria Bosinelui Bollettieri (eds), Bologna, CLUEB, pp. 297-306.

MunR, R. (2001): "Gesprächspartikeln und Pausenphänomene in deutschen, österreichischen und schweizerischen Alltagsszenarios." Modalità e substandard, Wilma HeInRICH and Christine Heiss (eds.), Bologna, CLUEB, pp. 87-108.

Nord, C.(1993): Einführung in das funktionale Übersetzen. Tübingen/Basel, Francke Verlag.

Picci, G. (2000): Il plurilinguismo nel dialogo filmico: da Le Mépris di Jean-Luc Godard a Il Disprezzo di Carlo Ponti. Tesi di Laurea (unpublished), SSLiMIT, Forlí.

Piccolo, M. (2000): Qualità e strategie nel doppiaggio del film Knocking on Heaven's Door di Thomas Jahn. Tesi di Laurea (unpublished), SSLiMIT, Forlí.

Pisek, G. (1994): Die große Illusion. Probleme und Möglichkeiten der Filmsynchronisation. Trier, WVT.

Pruys, G. M. (1997): Die Rhetorik der Filmsynchronisation. Tübingen, Gunter Narr Verlag.

Rossi, F. (1999): Le parole dello schermo. Analisi linguistica del parlato di sei film dal 1948 al 1957. Roma, Bulzoni.

SCHLeIERMACHER, F.D.E. (1835-1864): Ueber die verschiedenen Methoden des Uebersetzens. F.D.E. Schleiermacher, Sämmtliche Werke, Dritte Abtheilung, Berlin, pp. 207-245.

Soffritti, M. (1988): Ausklammerung und Standardsprache. Eine Untersuchung der Nachfeldbesetzung in SPIEGEL-Gesprächen 1986-1987, Bologna, Atesa. 